\title{
The notion of the Holy Spirit as Paraclete from a Pentecostal perspective
}

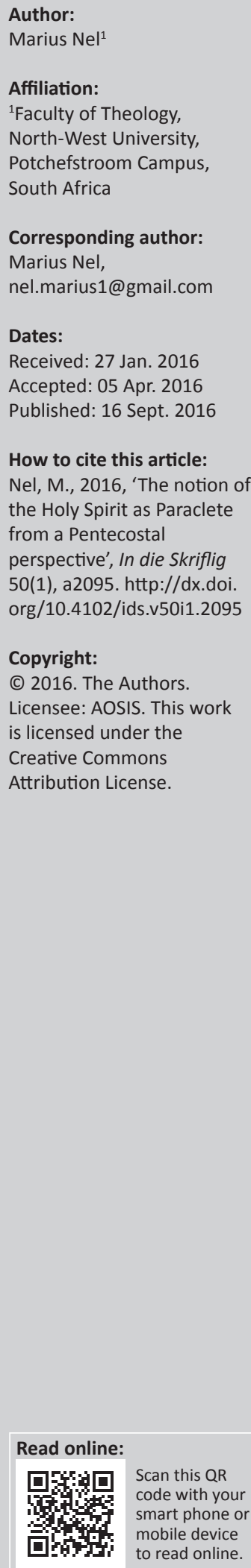

Pentecostals share an interest in the work and person of the Holy Spirit although not at the cost of a well-developed Christology. The term Paraclete ( $\pi \alpha \rho \alpha \dot{\alpha} \lambda \eta \tau о \varsigma)$ appears four times in the Gospel according to John in reference to the Holy Spirit (Jn 14:16, 26; 15:26; 16:7), and once in 1 John 2:1 in reference to Jesus. The question the article asks is: What is meant by the notion of the Spirit as Paraclete from a primarily Pentecostal perspective? To answer the question it is necessary to ask where John's Paraclete fits into the pneumatology of the early Christian Church before investigating the different contexts in the Johannine literature and what they suggest about the Spirit (and Jesus) as Paraclete. Lastly the meaning of the term in the GraecoRoman world of the 1st century CE is observed before some suggestions are made for interpreting Paraclete, specifically in forensic terms.

\section{Introduction}

Pentecostal theologians and pastors emphasise the person and work of the Holy Spirit (Becker 2004:42). Pretorius and Jafta (1997:221) claim in terms of Pentecostal churches, 'The Son, the second person of the Holy Trinity, is sometimes superseded by the Holy Spirit (cf. Jonker 1981:116). However, the accusation leveled at them that they do it at the cost of a well-developed Christology is not necessarily well-founded (Clark \& Lederle 1989:44; Möller 1997:140). Pentecostals believe and teach that the experience of an encounter with Christ is the result of the Spirit's revelation that never leaves a person neutral; the Spirit is after all the Spirit of Christ (Phlp 1:19; $1 \mathrm{Pt} 1: 11$ ) (Ma 2005:8). Christ forms the center of the Gospel, but what is critical for Pentecostals is the personal awareness and experiencing of encounters with the indwelling Spirit as the one who represents Jesus and his voice in the daily life of the believer (Jn 14:26) (Becker 2004:44; Kärkkäinen 1998:94). The revelation of Jesus Christ in the daily lives of believers is determined by the Spirit (Stronstad 1988:2). 'It is the Holy Spirit that calls, it is the Holy Spirit that inspires, it is the Holy Spirit that reveals and the Holy Spirit that administers (Wilson 1998:127).

Whilst Pentecostals believe that the Holy Spirit dwells in some sense, and to some extent, in every believer (Dayton 1987:24), there is yet another gift that Pentecostals expect and wait for, which Moody (Daniels 1877:396-403, quoting Moody) describes as the gift of the Spirit for service, and which is entirely distinct and separate from conversion with the acceptance of the forgiveness of sins (Walker 1993:429). Christians need this gift in order to be empowered for service (Harper 2008:105). McQueen (2009:3) explains that the endowment of this gift takes place in the context of a Pentecostal emphasis which is every believer's responsibility to be a witness of truth, grounded in a distinct belief in the priesthood and prophethood of all believers (Stronstad 1988:9). This is a gift of grace based on the promise of Acts 1:8 that God would reveal himself in a personal, immediate, intimate, and lasting way to believers by bringing humans under the control and fullness of his Spirit (Dempster 1989:4). This leads to their sensitised consciousness of the risen and glorified Christ in their lives, resulting in being more effective witnesses for Christ and worshipping him in a fuller dimension (Möller 1975:43-44).

Given this Pentecostal preference for the Spirit, the question asked in this article is how the notion of the Spirit as Paraclete is interpreted and explained from a primarily (although not exclusively) Pentecostal perspective. Preference will be given to resources by Pentecostal researchers.

The term Paraclete ( $\pi \alpha \rho \alpha \dot{\kappa} \lambda \eta \tau$ $)$ ) appears four times in the Gospel according to John in reference to the Holy Spirit (Jn 14:16, 26; 15:26; 16:7) and once in 1 John 2:1 in reference to Jesus. It is only used by John in the New Testament (Borchert 2002:121).

Note: This article is published as indicated from a Pentecostal perspective. At a later stage an article will be published where the same topic is researched from a classic Reformed perspective in order to promote the academic discourse on the subject of the doctrine of Pneumatology. 


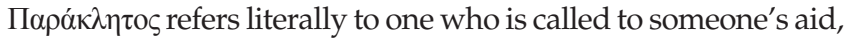
a lawyer, one who advocates another (Elwell \& Beitzel 1988:1614), an intercessor (Cross \& Livingstone 2005:1226), called to the side of (Smith 2011:739) or alongside to help (Strong 2003:1247), called in aid, or one who speaks in the defence of another person (Myers 1987:25). 'One called alongside to help' is derived from analysis of the passive verbal adjective consisting of two parts of the compound Greek word: para, meaning 'by' or 'with', and kaleō, meaning 'to call' (Turner 1992:349). Thus it is deduced that the Paraclete is one 'called alongside (to help)' (Carpenter \& Comfort 2000:255). Other interpreters relate the word toparaklēsis, whichmeans 'exhortation' or 'encouragement', hence the traditional rendering 'comforter'. However, what the function of the Paraclete in the Gospel of John is, must be discerned from the Gospel itself and not from dubious etymological arguments (Thompson 1992:382).

What does the context in the Johannine usage of Paraclete indicate in terms of the meaning of the term? Should it be understood in terms of 'comforter', 'exhorter', 'counselor', 'helper', 'teacher', or 'master', or are the functions attributed to the $\pi \alpha \rho \alpha ́ k \lambda \eta \tau o \varsigma$ in John 14-16 consistent with a forensic setting and the associated sense of 'advocate?'

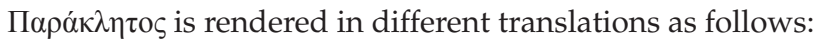

$\begin{array}{ll}\text { Comforter } & \text { KJV } \\ \text { Counselor } & \text { HCSB, RSV, NIV, NLT } \\ \text { Helper } & \text { NASB, ESV, NKJV, TEV } \\ \text { Advocate } & \text { NIV, NRSV, NET }\end{array}$

The first question that needs to be asked is where John's Paraclete fits into the pneumatology of the early Christian Church. Next, the different contexts of these passages and what they suggest about the Spirit and Jesus as Paraclete need to be investigated. Then it needs to be asked what the meaning of the term in the Graeco-Roman world of the 1st century CE denoted. And, lastly, in the synthesis some suggestions will be motivated for interpreting Paraclete. In the discussion of these questions, preference is primarily given to authors from a Pentecostal perspective in order to provide a Pentecostal perspective on the notion of the Spirit as Paraclete.

\section{Paraclete in the development of early Christian pneumatology}

Since Gunkel's (1979) important work of 1888 about the Spirit and its influence on believers most researchers do not accept that the early Christian Church had a unified and highly developed pneumatology from the very start, but that their pneumatology is the result of a process of development in their thinking about the work of the Spirit. The development can be seen when the different authors' works are compared. It seems that John as the last New Testament writer might have integrated these different insights (Ruthven 1969:8).

Paul, writing between 50 and 64 CE (DeSilva 2004:486-490), attributed soteriological functions to the Spirit that are not found in Mark, Luke-Acts or Matthew (Mittelstadt 2010:76;
Plüss 2003:19). The Spirit is first and foremost a soteriological agent in Pauline writings, as the source of cleansing (1 Cor

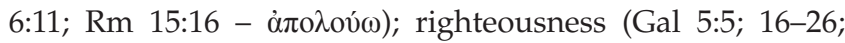

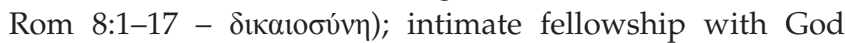
(Gl 4:6; Rm 8:14-17 - the Spirit allowing believers to cry, Abba Father (A $\beta \beta \alpha$ o $\pi \alpha \tau \eta ́ \rho)$; knowledge of God (1 Cor 2:6-16;

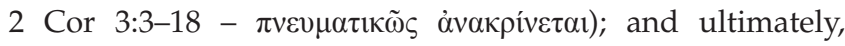
eternal life through the resurrection of Jesus (Rm 8:11; 1 Cor

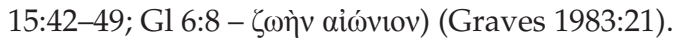

Luke-Acts, probably written between 70 and 90 CE (Carson \& Moo 2005:208; DeSilva 2004:298-299), has a much narrower focus of pneumatology which it shares with the synoptic Gospels. Luke views the Spirit as a gift that empowers the recipient to fulfill a divinely ordained task (Dempster 1989:5; Plüss 2003:19). This happens to John the Baptist whilst he was still in the womb (Lk 1:39-45) (Wenk 1995:5), Jesus at the Jordan (Lk 3:21-22) and during the transfiguration (Lk 9:34-36), and the disciples at Pentecost (Ac 2:1-13) (Mcmanus 1994:24). The Spirit comes upon them as the source of their prophetic imagination (Ruthven 1969:9), resulting in special insight and inspiring or ecstatic speech (Möller 1975:207). For Luke, as well as Mark and Matthew, the Spirit is not given as necessary for one to enter into salvation or remain within the community of the saved (Mittelstadt 2010:77; Zwiep 2007:133;). The function of the Spirit is seen in other terms, namely as endowment with the aim to fulfill a specific task related to a divine calling (Franck 1985:87; Stefan 2005:274). The coming of the Spirit is not related to soteriological functions, to cleanse or justify the believer, or as a prerequisite to know God and his will, or to be reminded of Jesus and his teaching (Franck 1985:89). The disciples receive the Spirit '... as a prophetic donum superadditum that enables them to participate effectively in the missionary enterprises of the church' (Joubert 2013:121; cf. Menzies 2010:43; Robeck 1983:24).

It seems that at least two distinct pneumatological perspectives co-existed in the traditions of the primitive church, the 'rather crude', in the view of Dunn (1975:190), prophetic pneumatology of the primitive church found in the Synoptic Gospels as well as Luke-Acts that limits the work of the Spirit to missionary enterprises (Dempster 1989:7; Shelton 1991:89), and Paul's soteriological pneumatology that links the Spirit to the experience of salvation (Zwiep 2007:142).

The Gospel of John was written between 80 and $95 \mathrm{CE}$ (Carson \& Moo 2005:267), integrating the themes and motifs found in Paul's epistles as well as the Synoptic Gospels and Luke-Acts (Plüss 2003:19). John provides a theological interpretation of the events sketched by the Synoptic Gospels (Ladd 1993:257). It becomes clear that John has specifically also absorbed and amalgamated Paul's pneumatological insights as well as the reflections of the primitive church (Dunn 1975:356; Stefan 2005:283). John in a certain sense writes his Gospel from the perspective of the work of the Spirit; this is why the Spirit features more prominently in John than the other Gospels (Neyrey 2007:245) and why John interprets the acting Jesus as well as the coming Jesus in terms of the Spirit's work (Stefan 2005:285). John interprets the Spirit in prophetic as well as soteriological terms, as an 
agent of inspiration as well as salvation and providing a synthesis of the diverse strands of pneumatology that functioned in the early church (Neyrey 2007:248).

In what way does John view the work of the Spirit? The question is important because its insights will provide the answer to the question how John's unique term for the Spirit, $\pi \alpha \rho \alpha ́ \kappa \lambda \eta \tau o \varsigma$, should be translated.

\section{Spirit in the Gospel according to John}

John sets the stage for his other passages about the function of the Spirit in John 3:5. Important for John is that the Spirit is the source of spiritual life, as explained in 3:5-8; 4:23-24; 6:63; and 7:37-39, emphasising the soteriological functions of the Spirit in the same terms as Paul in his epistles (Wenk 1995:11).

Jesus responds to Nicodemus' question how one can be born from above with, 'Truly, truly, I say to you, unless one is born of water and the spirit, he cannot enter the kingdom of God'

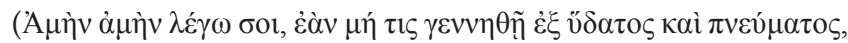

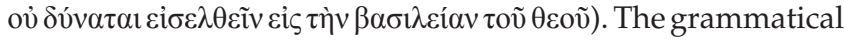
structure of the sentence, with a single preposition $(\dot{\varepsilon} \xi)$ governing the two nouns (v์ $\delta \alpha \tau \sigma \varsigma, \pi v \varepsilon v ́ \mu \alpha \tau o \varsigma)$ connected by $\kappa \alpha i$, indicates that the phrase does not refer to two distinct births but rather a single birth accomplished through a combination of water and spirit (Turner 1992:348; 1998:68). When Nicodemus professes his ignorance Jesus rebukes him: 'Are you the teacher of Israel and yet you do not understand

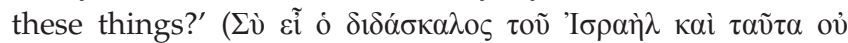
$\gamma$ should look for intertextual references in the Hebrew Bible; the teacher of Israel has the necessary equipment to understand these things (Robeck 1983:25). The most important reference is in Ezekiel 36:25-27 (Brown 1966:140; Michaels 1989:61; Milne 1993:76) that states that water would cleanse Israel from their impurities and idols, and they would receive a new heart and a new spirit when their heart of stone is removed and replaced with a heart of flesh. Yahweh would put his Spirit in them and move them to follow his decrees and be careful to keep his laws. In this way water, cleansing, and a new heart and spirit are associated, implying that 'water' and 'spirit' in John 3:5 should be interpreted as a reference to the cleansing transforming activity of the Spirit (Neve 2011:84-85). This way of interpreting John 3:5 is supported by 7:37-39 that states that rivers of living water

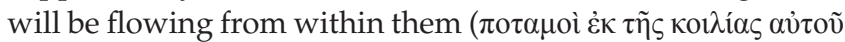

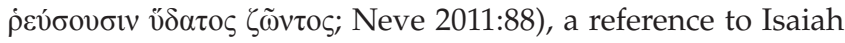
$58: 11$, as a metaphor for the life-giving work of the Spirit (Kärkkäinen 1998:95).

The birth of 'water and spirit' (Jn 3:5) qualifies them 'to be born again, or born from above' $(\gamma \varepsilon v v \eta \theta \tilde{n}$ öv $\omega \theta \varepsilon v$, to be understood as 'from above', 'from God', but ö $\omega \omega \theta \varepsilon v$ understood by Nicodemus as meaning 'again' and $\gamma \varepsilon v v \alpha ́ \omega$ as 'physical birth' (Louw \& Nida 1996:509-519). In other words, birth from above or to be born again is the precondition for a spiritual life, or entrance into the kingdom of God (or living in the right relationship with God, in Paul's terminology), and this new life is generated by the Spirit in the life of the believer (Smail 1994:73). In this way the Spirit is proposed as a soteriological agent when John 3:5 is read intertextually with Ezekiel 36:25-27.

The other passages referring to the work of the Spirit concurs with John 3:5. In 6:63 it is stated explicitly, 'It is the Spirit that gives life' ( of living water' are identified with the Spirit, emphasising that the Spirit is the source of spiritual life and salvation. The other reference, in 4:23-24, is more cryptic when it states that the Spirit who is God is a prerequisite for true worship. By

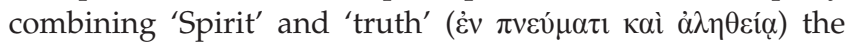
Spirit is described as the agent who reveals God's true identity (Suurmond 1990:106). In each of these passages the Spirit is viewed in terms of the source and agent of spiritual life (Stephenson 2009:51).

\section{Spirit as Paraclete in the Gospel according to John}

The latter part of the Gospel, in the midst of Jesus' farewell discourse, ${ }^{1}$ contains three texts speaking of the Spirit as the Paraclete (John 14:16-26; 15:26-27; 16:7-15). By utilising the term, John describes the Spirit in a unique manner. The question is, what dimension(s) of the Spirit's work does John wish to describe when he uses this term?

The distinctive of the Johannine Gospel is its compilation in a forensic setting, consisting of seven signs and seven public discourses in 2:1-12:50; the farewell discourse in 13:1-17:26; and the crucifixion in 18:1-19:42 and resurrection in 20:1-29. The purpose of the Gospel is stated in 20:30, '... so that you may believe that Jesus is the Christ, the Son of God, and that by believing you may have life in his name'. Throughout the Gospel, John features a trial motif accentuated by the use of courtroom terminology, especially the term witness (Billington 1995:97). It is also advanced by the discourses within the Gospel, where various parties question and interrogate one another and their explanations (Menzies 2010:47). The trial motif carries over into Jesus' farewell discourse, which forms the context of the Paraclete sayings and serves as introduction to Jesus' trial and execution (Billington 1995:100).

John 13-17 forms Jesus' upper-room discourse situated on the night before his crucifixion (Miller 2012:486). In the light of his approaching departure, he promises his disciples that he will not leave them alone (Beitzel 1988:1614). Borchert (2002:119) contends that John purposefully designed the farewell cycle in the form of a bull's eye of wraparound concentric circles with chapters 13 and 17 forming the outside ring around the prospect of Jesus' departure and its implications in 14:1-14, and 16:16-33 which forms the penultimate ring. In the center or core of the cycle, in $14: 15-16: 15$, the theme is the role of the Holy Spirit in the 1.An established Jewish genre, the farewell discourse forms the context for the Paraclete sayings (Turner 1992:349). 
light of Jesus' departure. It is in this center that the three Paraclete sayings occur.

\section{The first Paraclete statement: The coming of the Paraclete (Jh 14:15-17)}

After washing the feet of his disciples as a way of serving them in demonstration of his love and his injunction in v. 15, 'I have given you an example so that you also may do just as

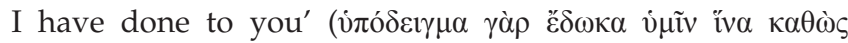

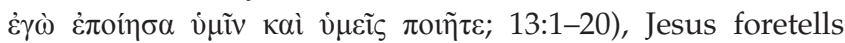
Judas' treachery (13:21-30). Then he announces in v. 33 his departure, '... where I am going you cannot come' ("O $\pi$ ov غ̇ $\gamma \grave{\omega}$

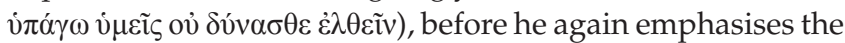

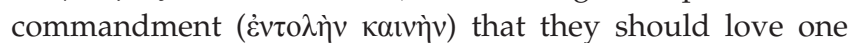
another, just as he has loved them. This will be the sign that they are his disciples (v. 35).

His words cause the disciples anxiety because he continues in 14:1, '... let not your [plural] heart [singular] be troubled'

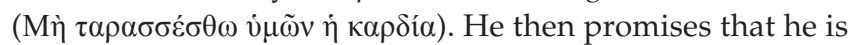
only going away to prepare a place for them, and when he is finished he will return to take them to himself, where in his Father's house there are many places, rooms or

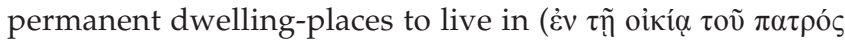

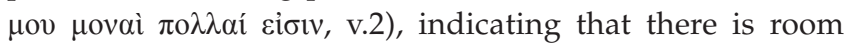
enough for all. In 14:10-11 he emphasises that he is in the

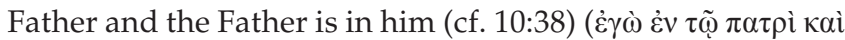
ó $\pi \alpha \tau \eta ̀ \rho ~ \dot{\varepsilon} v \dot{\varepsilon} \mu o$ í $\dot{\varepsilon} \sigma \tau \imath v)$. The implication is that he lives in the Father and the Father lives in him and they will meet the Father in him (Newman \& Nida 1993; Jn 14:10). And whoever believes in Jesus will perform the same works as

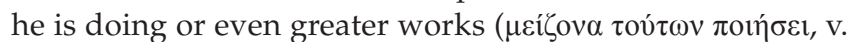
12), qualified by Newman \& Nida (1993; Jn 14:11) as 'wonderful things' or 'surprising accomplishments'. Whatever they ask in his name Jesus will do for them so that

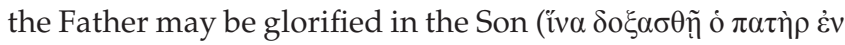
$\tau \tilde{\omega}$ vĩ̄, v. 14).

Then Jesus returns to the theme of love: if his disciples love him they will keep his commandments, injunctions,

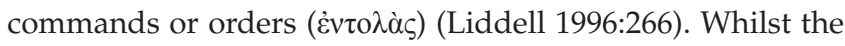
emphasis in chapter 13 was on the disciples' loving one another (13:34-35), which is repeated in 15:12-13, here the focus is shifted to the condition for loving Jesus, that they would do what he commands. Greek manuscripts provide several variants but the impact of the verse is clear, according to Borchert (2002:123), that obedience is a test or indication of loving Jesus, explicated also by 1 John 5:2-3. John does not define to which commandments Jesus refers, unlike Paul who details specific actions.

The connection between love, obedience and Jesus praying to (or asking) his Father for another Paraclete is not clear at first sight (Anderson 2002:26). Probably the connection is to be found in the requirement of love and obedience necessitating a resource of divine proportions. However, the gift of the Spirit is not quid pro quo between Jesus and his followers, as if the market exchange for the Spirit could be the disciples' obedience (Borchert 2002:124). In the process of responding to the Son, disciples discover that he has provided a divine agent that empowers them in this world (Menzies 1994:27). The Spirit will broker access to Jesus for believers, so that Jesus will continue to broker access to the Father and continue to be the 'way' to the Father (Jn 14:6). From a social approach, Brown (2003:211) suggests that 'broker' would indeed be warranted as a translation for $\pi \alpha \rho \alpha \dot{\alpha} \lambda \eta \tau$ o $\varsigma_{1}$ - one who mediates access to certain benefits from a patron who possesses those benefits. The Paraclete provides believers with access to Jesus, his past instruction and continuing revelation. But he also brokers access to another broker, Jesus, who brokers the benefits of the Father's patronage. This sort of network, Brown explains, occurs regularly in patronal relationships, concluding that Jesus' brokerage will continue in the work of

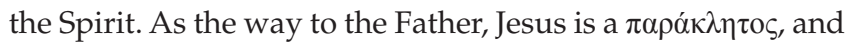
he continues to be the only one able to provide believers with access to God. The Spirit will be another $\pi \alpha \rho \alpha \dot{\alpha} \lambda \eta \tau \tau^{\circ}$, brokering access to Jesus after he left for the Father (Brown 2003:212).

The implication is that Jesus is a Paraclete, and the Spirit of truth is 'another' (ö $\lambda \lambda$ ov) Paraclete, that will serve as Jesus' substitute when he leaves for his Father's home. The Paraclete brokers truth by providing access to Jesus, the truth (Brown 2003:231). The term Paraclete is used only by John and each time refers to the Spirit (Jn 14:15, 26; 15:26; 16:7). It is never used in the Septuagint (Borchert 2002:124) to translate the 'Spirit' from Hebrew.

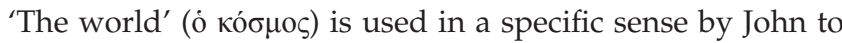
refer to the unbelieving world, hostile to Christ and all that he stands for, which is the significantly new use the term acquires in the New Testament (Morris 1971:126-128).

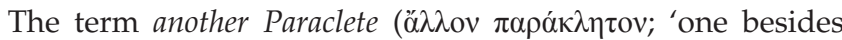
himself', Liddell 1996:38) is qualified in terms of the Spirit

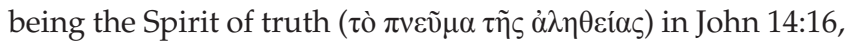
who will be with them forever, for their generation or age, for a long space of time, or for a specific period ( (Louw \& Nida 1988:641-642; 67.95). John attributes truth to Jesus - he speaks the truth and is the truth $(1: 14,17 ; 8: 30$, $45-46 ; 14: 6)$, his disciples follow the truth $(4: 23-24 ; 8: 32$; $18: 37)$, contra the devil ( $\delta 1 \alpha \beta$ ótos) who is a liar and whose nature is opposed to the truth (8:44). The Paraclete is an agent of truth (Suurmond 1990:106). That the title 'Spirit of truth' is employed in conjuction with the phrase '... whom the world cannot receive', signifies that the Spirit stands alienated to the world, the realm of falsehood (Brown 2003:204).

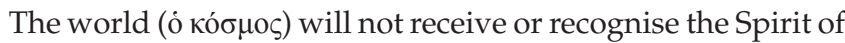
truth. In John's ethical dualistic thinking the believers and the world form two realms that are poles apart (Borchert 2002:125; Van der Watt 2005:126). Bultmann (1971:616) states that the world cannot receive the Spirit without giving up its essential nature, that which makes it the world. John addresses his Gospel to a community pressured by the surrounding hostile world and that sets itself over against the world (Haenchen 1984:126). 


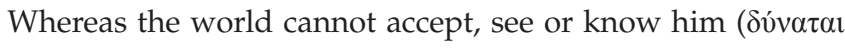

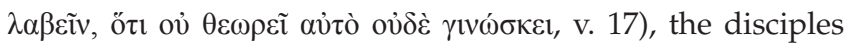
know him because he is with, remains or abides in them (ö $\tau$

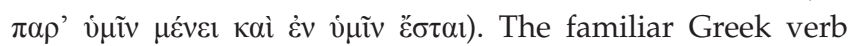
signals a sense of a relationship that is not merely transitory; the disciples are encouraged to abide in the true vine (Jn 15:4-5, 7) (Smail 1994:87). Here the Paraclete is abiding with the community (plural: $\dot{v} \mu \varepsilon \bar{\varsigma}$ ), exhorting and encouraging them through the preaching of the apostolic witness. ${ }^{2}$

Traditionally, Pentecostal studies choose to differentiate between the Spirit abiding with and in believers, with the first referring to the act of regeneration and the second to the baptism in the Spirit (Story 1991:1603). However, the verbs

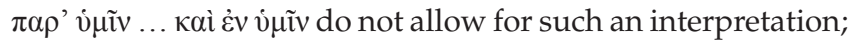
the primary meaning of para is 'alongside of', which suggests that someone has been with them all the time, indicating Jesus as the one in whom the Spirit lives in full measure. When Jesus departs, the Spirit will dwell in the disciples and become their guide (Jn 16:13). The text does not refer to or allow for a two-stage salvation process.

\section{The second Paraclete statement: Interpreter of Jesus (Jn 14:25-31)}

Whilst the '... dull, dirgelike beat of Jesus' departure continues to echo' (Borchert 2002:169) throughout the farewell discourse, here the focus is on statements or teachings of Jesus during the period that he remained with (alongside) them ( $\pi \alpha \rho$ ' $\dot{\gamma} \mu \mathrm{i} v \mu \varepsilon \dot{v} \omega v ; 14: 25)$ in his role as their (first) Paraclete. A new era will dawn, of the Holy Spirit

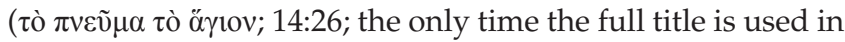
the farewell discourse, and only one of three uses in the entire Johannine corpus, along with $1: 33 ; 20: 22$ ). The function of the Spirit is of a prompter, one who brings to memory what Jesus taught, confirming and interpreting the message proclaimed and demonstrated by Jesus (Edwards 2003:149). He will teach the disciples everything ( $\delta 1 \delta \alpha \dot{\xi} \varepsilon 1 \pi \alpha \dot{v} \tau \tau)$ and remind

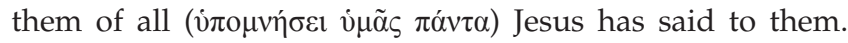
Jesus insists that his teaching is not his own (5:19); in the same sense the Spirit would interpret Jesus' teaching, continuing Jesus' revelation and taking it to a deeper level (Schnackenburg 1987:83).

In John 14:27 Jesus then offers a farewell to his disciples:

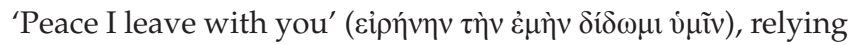
on the Semitic expression of greeting and functioning in the Pax Romana of Augustus and his successors (Duffield \& Van Cleave 1983:286). But Jesus' peace is different, the peace of God in the world. The peace would calm their troubled hearts and ease their fears of his departure (Borchert 2002:170).

In this way, the argument is closed and Jesus adds, 'Rise, let

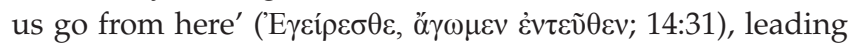

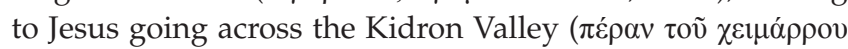

\footnotetext{
2.The New Testament contains more than 299 occurrences of "witness" and its cognates, and approximately $40 \%$ are found in the Johannine literature. 'To testify' occurs 76 times in the New Testament and 33 times in the Gospel of John occurs 76 times in the New Testament and 33 times in the Gospel of John.
'Testimony' occurs 37 times in the New Testament and 14 times in John's Gospel (Menzies 2010:47).
}

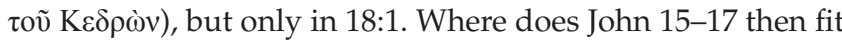
in? Many solutions have been offered, including several rearrangement theories, but it seems important that any argument should not disturb the logic of the tightly knit argument in the farewell discourse that follows in 15-17 in conjunction with 13:31-14:31 (Suurmond 1988:12).

\section{The third Paraclete statement: Witness in persecution (Jh 15:26-16:4a)}

This passage appears in a setting that highlights that the world will reject Jesus as well as his disciples: 'If they

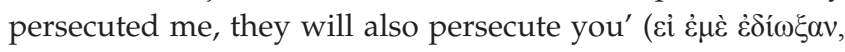

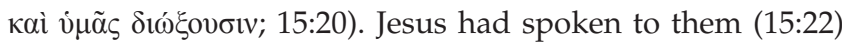
and performed the works that no one else did (15:24); however, the world still rejected him. And his disciples will

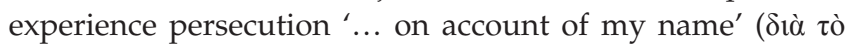

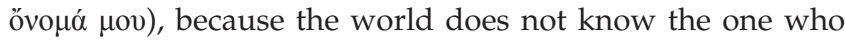
sent Jesus (15:21). In this way the world's guilt will be

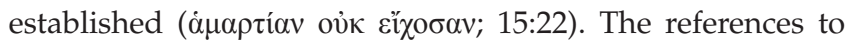
witness, guilt, sin and conflict establish that this passage is written in a forensic sense (Franck 1985:101). This sense is extended by the reference in 15:26 to the Paraclete's specific

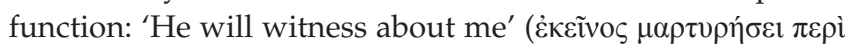
$\dot{\varepsilon} \mu$ ov). What will he witness about Jesus? That the world unjustly rejected Jesus who died on the cross whilst he is in reality the Son of God, the agent of salvation sent by the Father, a theme developed further in 16:8-11. The forensic sense is clear (Franck 1985:116; Kay 1999:98), demonstrated in the parallelism between the conception of the Paraclete as witness and the portrayal of the Spirit's work to witness for the disciples before the courts in the Synoptic 'Eschatological Discourse' (Mk 13:9-13; Mt 10:17-25; 24:9-10; Lk 21:12-17), suggesting that John knew the Synoptic traditions and reformulated them to suit his purposes (Brown 2003:217).

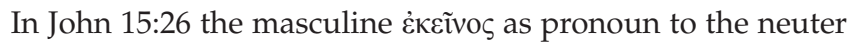
noun 'Spirit' ( $\tau$ ò $\pi v \varepsilon \tilde{v} \mu \alpha$ ), is unusual, indicating that the author considers the Spirit as a personal being and not something impersonal, a force. The role of the $\pi \alpha \rho \alpha \dot{\alpha} \lambda \eta \tau \tau \varsigma$ is to testify or witness concerning Jesus, in association and in harmony with the disciples (Borchert 2002:170). The Spirit

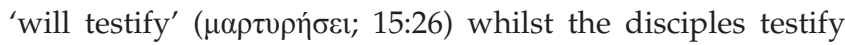
(indicative or imperative - $\mu \alpha \rho \tau \rho \rho \varepsilon \tau \varepsilon)$ (15:27; Franck 1985:104). Normally the imperative is chosen by exegetes because it represents a continuing command to the disciples. However, the sense rather seems to be that the disciples, those with Jesus from the beginning of his ministry, are already witnessing whilst the Spirit will only commence when Jesus' ministry ends (Suurmond 1988:14). The Paraclete is not sent to the world and cannot guide the world in all truth as he does the disciples. The only way the Spirit's witness can reach the world is through the disciples; the Paraclete witness to the world through the proclamation of believers (Brown 2003:216-217).

The danger is that the disciples might fall away, stumble, become offended, go astray or be scandalised ( $\sigma \kappa \alpha v \delta \alpha \lambda 1 \sigma \theta \tilde{\eta} \tau \varepsilon ; 16: 1)$. 
The verb in the passive voice has the sense of 'to give up one's faith' or 'fall into sin' (Strong 2009:65), as happened already to some, in John 6:61 (active voice) and 6:66. The

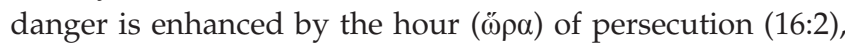
reminding of Jesus' $\omega \rho \alpha$ that is fast approaching $(17: 1 ; 19: 30)$. And the persecutors would actually think that they were serving God by seeking to stamp out religious error (Anderson 2002:26). But the disciples should not try to escape persecution; this is the time for witnessing when Jesus has gone away and the Paraclete has come to help them (Franck 1985:115)

\section{The fourth Paraclete statement: Counselor and judge (Jn 16:4b-11)}

Jesus explains why he has not told them before of the coming

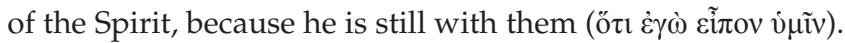
But now (vข̃v) a new era is dawning and everything is about to change. Jesus' role is ending and he will leave them to be with his Father who has sent him.

The disciples are filled with sorrow ( $\dot{\eta} \lambda \hat{v} \pi \eta \pi \varepsilon \pi \lambda \eta \dot{\rho} \rho \omega \kappa \varepsilon v \dot{v} \mu \tilde{\omega} v$ $\tau \eta े v ~ \kappa \alpha \rho \delta i ́ \alpha v)$, with a verb in perfect voice being used ( $\pi \varepsilon \pi \lambda \eta \dot{\rho} \omega \kappa \varepsilon v)$ that seems strange (Morris 1971:617), except if it is interpreted as a time-oriented sequential statement (Borchert 2002:173). The word used for grief $(\lambda v i \eta \eta)$ is also used in 16:20, 22 linking it verbally with the next section of the discourse.

John 16:7-11 is characterised by several exegetical difficulties but the essential meaning is clear. The Paraclete will bring Jesus' case before the world (of unbelievers) and convict

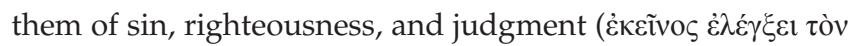

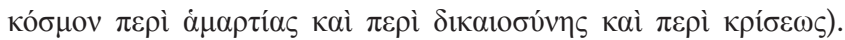
$\dot{\varepsilon} \lambda \dot{\varepsilon} \gamma \xi \varepsilon 1$ means to prove, convince, convict, prove wrong, expose as guilty, or reprove (Newman \& Nida 1993:503) which constitutes that the Paraclete is primarily a forensic figure (contra Brown 2003:227 who implausibly argues that the $\dot{\varepsilon} \lambda \dot{\varepsilon} \gamma \xi \varepsilon 1$ work of the Paraclete is of a competition between brokers, where the Paraclete demonstrates to the disciples the unworthiness of the rival broker, the synagogue). He will as their advocate support their witness in the world (Turner 1998:87) and lend in court the weight of his influence and prestige to the case in order to convince the judges of his probity (Brown 2003:219). The Paraclete will do the witnessing work, not by an inward testimony in the hearts of the world, but through the outward testimony of words spoken by the disciples (Michaels 1989:282). This conclusion is supported by John 15:26-27, that the Paraclete will testify about Jesus, but the disciples also must testify. John 16:1-4 adds that the Paraclete will enable disciples to stand firm even if they are persecuted and to testify or witness boldly about Jesus (Michaels 1989:277; Kay 1999:99).

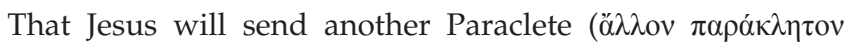
$\delta \omega ́ \sigma \varepsilon 1 ; 14: 16)$, indicates that Jesus served as a Paraclete during his earthly ministry. 'Another' (ä $\lambda \lambda \nu^{\circ}$ ) refers to another of the same kind, implying that the Spirit is Jesus' personal substitute and representative (Miller 2012:486).
The continuity between Jesus and the paraclete is the most dominant feature of the Paraclete passages; the resemblance between John 14:15-17 and 14:18-21 reinforces the idea that the Paraclete's coming fulfills Jesus' promise to return or is portrayed as a stage in that fulfillment (Brown 2003:191). This is higlighted further in 16:12-15, indicating that the work of Jesus and the Spirit is one and the same at this point, to confront a hostile and unbelieving world (Billington 1995:109-110). For this reason the disciples will not be

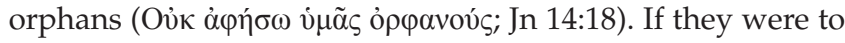
be left alone in the world they would have been helpless, unable to prosecute their case against the world. But now they are not alone; they have an advocate who helps and directs them, and raises awareness of the presence of the glorified Christ (Möller 1994:224). Essentially, the Paraclete perpetuates the presence of Jesus by brokering access to Jesus after he has departed (Brown 2003:232). Like God and Jesus, Jesus and the Paraclete at certain points in this discourse seem to collapse into one character, demonstrating a functional unity (Brown 2003:265). Jesus concludes his conversation about the Paraclete by stating that he still has many things to tell his disciples but that they cannot bear it now, and that the Spirit will come and guide them in all truth, speaking of things to come (Jn 16:12-13). Here the Paraclete fulfills one of the key roles of a prophet (Brown 2003:211) and he provides a way for Jesus to continue to be a Paraclete (Brown 2003:233).

The answer to the question whether the functions attributed to the $\pi \alpha \rho \alpha \dot{\kappa} \lambda \eta\rceil$ ○ $\varsigma$ in John 14-16 are consistent with a forensic setting is confirmed, leading to the conclusion that Paraclete should be interpreted in terms of 'advocate' (Luz 2006:60). The forensic setting is confirmed by references to the disciples' and Spirit's witness and testifying, and the world's rejection of Christ, even in the face of his words (Jn 15:22) and deeds (15:24), establishing its guilt. The repeated references to conflict, guilt and witness establish the forensic character of these passages (Menzies 2010:48).

\section{Paraclete in the Graeco-Roman world of the 1st century CE}

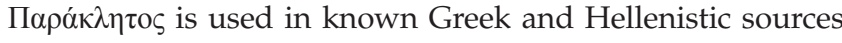
outside the New Testament to depict a legal advisor, helper or advocate in the context of a court setting (Behm 1964:803; Van Voorst 1990:29), one who is a legal assistant or friend at court, a person of sufficient reputation to influence the king, emperor or other sovereign (Thompson 1992:382). The accused or defending party in the court without legal abilities can become the victim of clever legal sharks and needs somebody who can help them. And for this reason courts allowed somebody that can be called alongside the party, an advocate, who offers counsel and assistance in the court or dispute.

1 John 2:1 is the only other place in the New Testament where $\pi \alpha \rho \alpha \dot{\kappa} \lambda \eta \tau$ os occurs outside the Gospel, stating that believers who sin have a $\pi \alpha \rho \alpha ́ k \lambda \eta \tau o \varsigma$, one called alongside to help, with

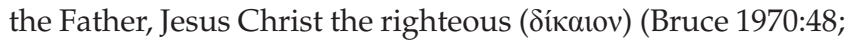
Cronjé 1981:24-25; Marshall 1978:115). The reference to the 
believer's sin before the Father's throne creates the impression of a courtroom where judgment will be handed down about the guilt of the sinner (Brown 1982:239; Creech 2003:31; Luz 2006:60). This depiction in a forensic setting accords well with the manner in which the term was used in literature outside the New Testament, as well as in John's Gospel (Bruce 1970:49-50).

\section{Synthesis}

The analysis of the different passages in the light of the contributions of Pentecostal exegetes indicates that a primary forensic context of a judicial trial and prosecution presents the most likely catalyst for John's introduction of the term Paraclete (Burge 1987:205). John features consistently throughout his Gospel the motif of a trial, accentuated by his usage of courtroom terminology, especially 'witness'. The discourses in the Gospel are in forensic form with various parties questioning and interrogating one another, and the explanations given to the interrogation (Billington 1995:90). The trial motif also carries over into Jesus' farewell discourse, which forms the context for the Paraclete sayings and serves as introduction to Jesus' trial before the Jewish and Roman courts. Reminding them of his imminent departure, Jesus assures his disciples that they will not be left alone because he will send another Paraclete, an advocate who will aid them in the cosmic trial that is already underway between Jesus and the unbelieving world, and implicating the disciples (Billington 1995:100; Menzies 1994:48).

The trial context of John's Gospel and the forensic terminology in the Paraclete passages distinguish the Paraclete's distintive role and function. He comes to the disciples as their advocate, assisting them to represent the case of Christ against the world by enabling bold witnessing, even in the face of persecution and opposition (Möller 1994:232). Brown (2003:211) adds another perspective from a social approach, namely, that the Spirit will broker access to Jesus for believers, as Jesus brokers access to the Father. 'Broker' refers to one who mediates access to certain benefits from a patron who possesses those benefits. The Paraclete will provide believers with access to Jesus' past instruction and continuing revelation whilst Jesus brokers the benefits of the Father's patronage. Brown (2003:218) argues then that the 'forensic' task of the Spirit-Paraclete falls within this patronal function, with the work of the Spirit concomitant to his role as Jesus' loyal broker/client and as a support to the disciples in their work of witnessing. However, this is to negate the context of the Paraclete sayings within the Gospel, of a trial motif fashioned by the author. It seems that the Paraclete should rather be interpreted as the advocate who brokers Jesus' presence to the disciples in a hostile world and during their trials. Patrons frequently provide their clients with support during times of need; such support constitutes a key benefit of the patronal relationship (Brown 2003:219) and can readily be reconciled with the forensic meaning of $\pi \alpha \rho \alpha \dot{\alpha} \lambda \eta \tau$ ○.

If Paul articulated the soteriological aspects of the work of the Spirit and the synoptic Gospels as a prophetic pneumatology, then John's Gospel is the synthesis of these two strands. John stresses the salvific value of the coming of the Spirit whilst the Spirit also has the power which enables disciples to bear witness, illustrating the diversity and development in early pneumatology in the primitive church. The clear context of the Gospel, with its extended trial motif, suggests that $\pi \alpha \rho \alpha \dot{\alpha} \lambda \eta \tau$ $\lambda$ should be translated and interpreted in forensic terms. In John's pneumatological perspective, the

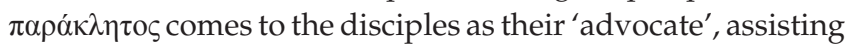
them in representing Christ before an unbelieving world.

\section{Acknowledgements Competing interests}

The author declares that he has no financial or personal relationships which may have inappropriately influenced him in writing this article.

\section{References}

Anderson, A., 2002, 'Christian missionaries and "heathen natives:" The cultural ethics of early Pentecostal missionaries', The Journal of the European Pentecostal Theological Association XXII, 4-29. http://dx.doi.org/10.1179/jep.2002.22.1.002

Becker, M., 2004, 'A tenet under examination: Reflections on the Pentecostal hermeneutical approach', The Journal of the European Pentecostal Theological Association XXIV, 30-48. http://dx.doi.org/10.1179/jep.2004.24.1.004

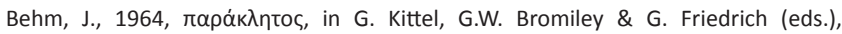
Theological dictionary of the New Testament, electronic ed., vol. 5, pp. 800-814, Eerdmans, Grand Rapids, MI.

Beitzel, B.J., 1988, 'Paraclete', in W.A. Elwell \& B.J. Beitzel (eds.), Baker Encyclopedia of the Bible, p. 1614. Baker Book House, Grand Rapids, MI.

Billington, A., 1995, 'The Paraclete and mission in the Fourth Gospel', in A. Billington, T. Lane \& M. Turner (eds.), Mission and meaning: Essays presented to Peter Cotterell, pp. 90-115, Paternoster, Carlisle.

Borchert, G.L., 2002, John 12-21: An exegetical and theological exposition of Holy Scripture, The New American Commentary, Broadman \& Holman, Nashville, TN.

Brown, R., 1966, The Gospel according to John, vol. 1, Anchor Bible, Garden City, NY.

Brown, R.E., 1982, The Epistles of John, The Anchor Bible, London.

Brown, T.G., 2003, Spirit in the writings of John: Johannine pneumatology in socialscientific perspective, T\&T Clark, London.

Bruce, F.F., 1970, The Epistles of John: A verse by verse exposition, Pickering \& Inglis, London.

Bultmann, R.K., 1971, The Gospel of John: A commentary, The Johannine Monograph Series, Westminster, MD

Burge, G., 1987, The anointed community: The Holy Spirit in the Johannine community, Eerdmans, Grand Rapids, MI.

Carpenter, E.E. \& Comfort, P.W., 2000, Holman treasury of key Bible words: 200 Greek and 200 Hebrew words defined and explained, Broadman \& Holman, Nashville, TN.

Carson, D.A. \& Moo, D.J., 2005, An introduction to the New Testament, 2nd edn., Apollos, Leicester, MD.

Clark, M.S. \& Lederle, H.I., 1989, What is distinctive about Pentecostal theology? Miscellanea Specialia 1, University of South Africa, Pretoria.

Creech, R.R., 2003, 'Advocate', in C. Brand et al. (eds.), Holman illustrated Bible dictionary, pp. 31-33, Holman Bible Publishers, Nashville, TN.

Cronjé, F., 1981, Waarom Pinkster: Die rol van die Heilige Gees in die ontstaan van die Nuwe Testamentiese kerk, en die leer oor saligheid, Evangelie Uitgewers, Johannesburg.

Cross, F.L. \& Livingstone, E.A. (eds.), 2005, The Oxford Dictionary of the Christian church, 3rd edn., Oxford University Press, New York.

Daniels, W.H. (ed.), 1877, Moody: His words, works, and workers, Nelson and Phillips, New York.

Dayton, D.W., 1987, Theological roots of Pentecostalism, Hendrickson, Peabody, MA.

Dempster, M.W., 1989, 'The church's moral witness: A study of glossolalia in Luke's theology of Acts', Paraclete 23(I), 1-7.

DeSilva, D.A., 2004, An introduction to the New Testament: Contexts, methods \& ministry formation, IVP Academic, Downers Grove, IL.

Duffield, G.P. \& Van Cleave, N.M., 1983, Foundations of Pentecostal theology, L.I.F.E. Bible College, Los Angeles, CA.

Dunn, J.G., 1975, Jesus and the Spirit: A study of the religious and charismatic experience of Jesus and the first Christians as reflected in the New Testament, $\mathrm{SCM}$, London. 
Edwards, R., 2003, Discovering John, Society for Promoting Christian Knowledge, London.

Elwell, W.A. \& Beitzel, B.J., 1988, Bakers encyclopedia of the Bible, Baker, Grand Rapids, MI.

Franck, E., 1985, 'Revelation taught: The Paraclete in the Gospel of John', Coniecatenea Biblica, New Testament Series 14, PhD dissertation, Uppsala University, Malmo.

Graves, R.W., 1983, 'Tongues shall cease: A critical survey of the supposed cessation of the charismata', Paraclete 17, 20-28.

Gunkel, H., 1979, The influence of the Holy Spirit: The popular view of the apostolic age and the teaching of the apostle Paul, transl., R.A. Harrisville \& P.A. Quanbeck, Fortress, Philadelphia, PA

Haenchen, E., 1984, John 2: A commentary on the Gospel of John, Chapters 7-21, Hermeneia: A critical and historical commentary on the Bible, Fortress, Minneapolis, MN.

Harper, M., 2008, 'The waves keep coming in', The Journal of the European Pentecostal Theological Association 28(2), 102-117. http://dx.doi.org/10.1179/jep.2008.28.2.002

Jonker, W.D., 1981, Die Gees van Christus, NG Kerkboekhandel, Pretoria.

Joubert, S., 2013, 'Not by order, nor by dialogue: The metanoetic presence of the kingdom of God in a fluid new world and the church', Acta Theologica 33(1) 114-134.

Kärkkäinen, V.-M., 1998, 'Pentecostal hermeneutics in the making: On the way from fundamentalism to postmodernism', The Journal of the European Pentecostal Theological Association XVIII, 76-115. http://dx.doi.org/10.1179/ jep.1998.18.1.006

Kay, P., 1999, 'The Pentecostal Missionary Union and the fourfold gospel with baptism in the Holy Spirit and speaking in tongues: A new power for missions?', The Journal of the European Pentecostal Theological Association XIX, 89-104. http:// dx.doi.org/10.1179/jep.1999.19.1.007

Ladd, G., 1993, A theology of the New Testament, rev. edn., Eerdmans, Grand Rapids, MI.

Liddell, H.G., 1996, A lexicon: Abridged from Liddell and Scott's Greek-English lexicon Logos, Oak Harbor, WA

Louw, J.P. \& Nida, E.A., 1988, Greek-English lexicon of the New Testament, I: Introduction \& Domains. United Bible Societies, New York.

Louw, J.P., \& Nida, E.A., 1996, Greek-English lexicon of the New Testament: Based on semantic domains, electronic edn., 2nd edn., vol. 1, United Bible Societies, New York.

Luz, U., 2006, 'Empowerment and commission in the New Testament', The Journal of the European Pentecostal Theological Association XXVI(1), 49-62. http://dx.doi. org/10.1179/jep.2006.26.1.005

Ma, W., 2005, 'Full circle mission: A possibility of Pentecostal missiology', Asian Journal of Pentecostal Studies 8(1), 5-27.

Marshall, I.H., 1978, The Epistles of John, The New International Commentary on the New Testament, Eerdmans, Grand Rapids, MI.

Mcmanus, J., 1994, Healing in the Spirit: Inner healing and deliverance in today's church, Darton, Longman \& Todd, London.

McQueen, L.R., 2009, Joel and the Spirit: The cry of a prophetic hermeneutic' CPT, Cleveland, $\mathrm{OH}$.

Menzies, R.P., 1994, Empowered for witness, Sheffield Academic Press, Sheffield

Menzies, R.P., 2010, The language of the Spirit: Interpreting and translating charismatic terms, CPT, Cleveland, $\mathrm{OH}$.

Michaels, J.R., 1989, John, NIBC 4, Hendrickson, Peabody, MA.

Miller, J.E., 2012, 'Paraclete', in J.D. Barry et al. (eds.), The Lexham Bible Dictionary pp. 485-487, Lexham, Bellingham, WA.

Milne, B., 1993, The message of John, Inter-Varsity Press, Leicester, MA.

Mittelstadt, M.W., 2010, Reading Luke-Acts in the Pentecostal tradition, CPT, Cleveland, $\mathrm{OH}$.

Möller, F.P., 1975, Die diskussie van die charismata soos wat dit in die Pinksterbeweging geleer en beoefen word, Evangelie Uitgewers, Braamfontein.

Möller, F.P., 1994, Woord van lig en lewe, deel III, Evangelie Uitgewers, Johannesburg.

Möller, F.P., 1997, 'Christ and Pentecostalism', in P.J. Gräbe \& W.J. Hattingh (eds.) The reality of the Holy Spirit in the church: In honour of F.P. Möller, pp. 140-144, Van Schaik, Pretoria.
Morris, L., 1971, The Gospel according to John, New International Commentary on the New Testament, Eerdmans, Grand Rapids, MI.

Myers, A.C., 1987, The Eerdmans Bible dictionary' Eerdmans, Grand Rapids, MI.

Neve, L.R., 2011, The Spirit of God in the Old Testament, Centre for Pentecostal Theology Classics Series, CPT, Cleveland, $\mathrm{OH}$.

Newman, B.M. \& Nida, E.A., 1993, John: A translator's handbook on the Gospel of John, United Bible Societies, New York.

Neyrey, J.H., 2007, The Gospel of John, The New Cambridge Bible Commentary, Cambridge University Press, Cambridge.

Plüss, J.-D., 2003, 'Religious experience in worship: A Pentecostal perspective', PentecoStudies 2(1), 1-21.

Pretorius, H. \& Jafta, L., 1997, 'A branch springs out": African Initiated Churches', in R. Elpjick \& R. Davenport (eds.), Christianity in South Africa: A political, social, and cultural history, pp. 211-226, University of California Press, Berkeley, CA.

Robeck, C.M., 1983, 'Hippolytus on the gift of prophecy', Paraclete 17(3), 22-27.

Ruthven, J., 1969, 'The cessation of charismata: Part one: A survey of a prevailing viewpoint', Paraclete 3(2), 1-11.

Schnackenburg, R., 1987, The Gospel according to St. John, Crossroad, New York.

Shelton, J., 1991, Mighty in word and deed: The role of the Holy Spirit in Luke-Acts, Hendrickson, Peabody, MA.

Smail, T., 1994, The giving gift: The Holy Spirit in person, 2nd edn., Darton, Longman \& Todd, London.

Smith, D.M., 2011, 'Paraclete', in M.A. Powell (ed.), The HarperCollins Bible Dictionary, p. 739. rev., 3rd edn., HarperCollins, New York.

Stefan, C., 2005, 'The Paraclete and prophecy in the Johannine Community', Pneuma 27(2), 273-296.

Stephenson, C.A., 2009, 'Pentecostal theology according to the theologians: An introduction to the theological method of Pentecostal systematic theologians', PhD dissertation, Marquette University, viewed n.d., from http://epublications. marquette.edu/dissertations mu/9

Story, E.L., 1991, 'The Gospel according to John,' in J.W. Hayford (ed.), Spirit filled life Bible: A personal study Bible unveiling all God's fullness in all God's Word, pp. 1571-1617, Thomas Nelson, Nashville, TN.

Strong, J., 2009, A concise dictionary of the words in the Greek Testament and the Hebrew Bible, vol. 1, Logos, Bellingham.

Strong, T., 2003, 'Paraclete', in C. Brand et al. (eds.), Holman illustrated Bible Dictionary, p. 1247, Holman, Nashville, TN

Stronstad, R., 1988, 'Trends in Pentecostal hermeneutics', Paraclete 22(3), 1-12.

Suurmond, J.-J., 1988, 'De gaven van onderscheiding', Bulletin voor charismatische theologie 22, 1-17. http://dx.doi.org/10.2143/bij.51.2.2015391

Suurmond, J.-J., 1990, 'The meaning and purpose of Spirit-baptism and the charisms', The Journal of the European Pentecostal Theological Association IX(4), 96-131. http://dx.doi.org/10.2143/bij.51.2.2015391

Thompson, M.M., 1992, 'John, Gospel of', in J.B. Green \& S. McKnight (eds.), Dictionary of Jesus and the Gospels, p. 382, InterVarsity, Downers Grove, IL.

Turner, M., 1998, The Holy Spirit and spiritual gifts in the New Testament church, rev edn., Hendrickson, Peabody, MA

Turner, M.M.B., 1992, 'Holy Spirit', in J.B. Green \& S. McKnight (eds.), Dictionary of Jesus and the Gospels, pp. 341-351. InterVarsity, Downers Grove, IL.

Van der Watt, J.G., 2005, Soteriology of the New Testament: Perspectives on soteriology, Novum Testamentum 121, Brill, Leiden.

Van Voorst, R.E., 1990, Building your New Testament Greek vocabulary, Eerdmans, Grand Rapids, Ml.

Walker, A., 1993, 'Pentecostalism and charismatic Christianity', in A.E. McGrath (ed.), The Blackwell Encyclopedia of modern Christian thought, pp. 428-434, Blackwell, Oxford.

Wenk, M., 1995, 'Reconciliation and reversal: John's pneumatic ministry', The Journa of the European Pentecostal Theological Association XIV, 5-21. http://dx.doi org/10.1179/jep.1995.14.1.002

Wilson, E., 1998, Strategy of the Spirit: J. Philip Hogan and the growth of the Assemblies of God worldwide 1959-1990, Regnum, Oxford.

Zwiep, A.W., 2007, 'Luke's understanding of baptism in the Spirit: An evangelical perspective', PentecoStudies 6(2), 127-149. 